
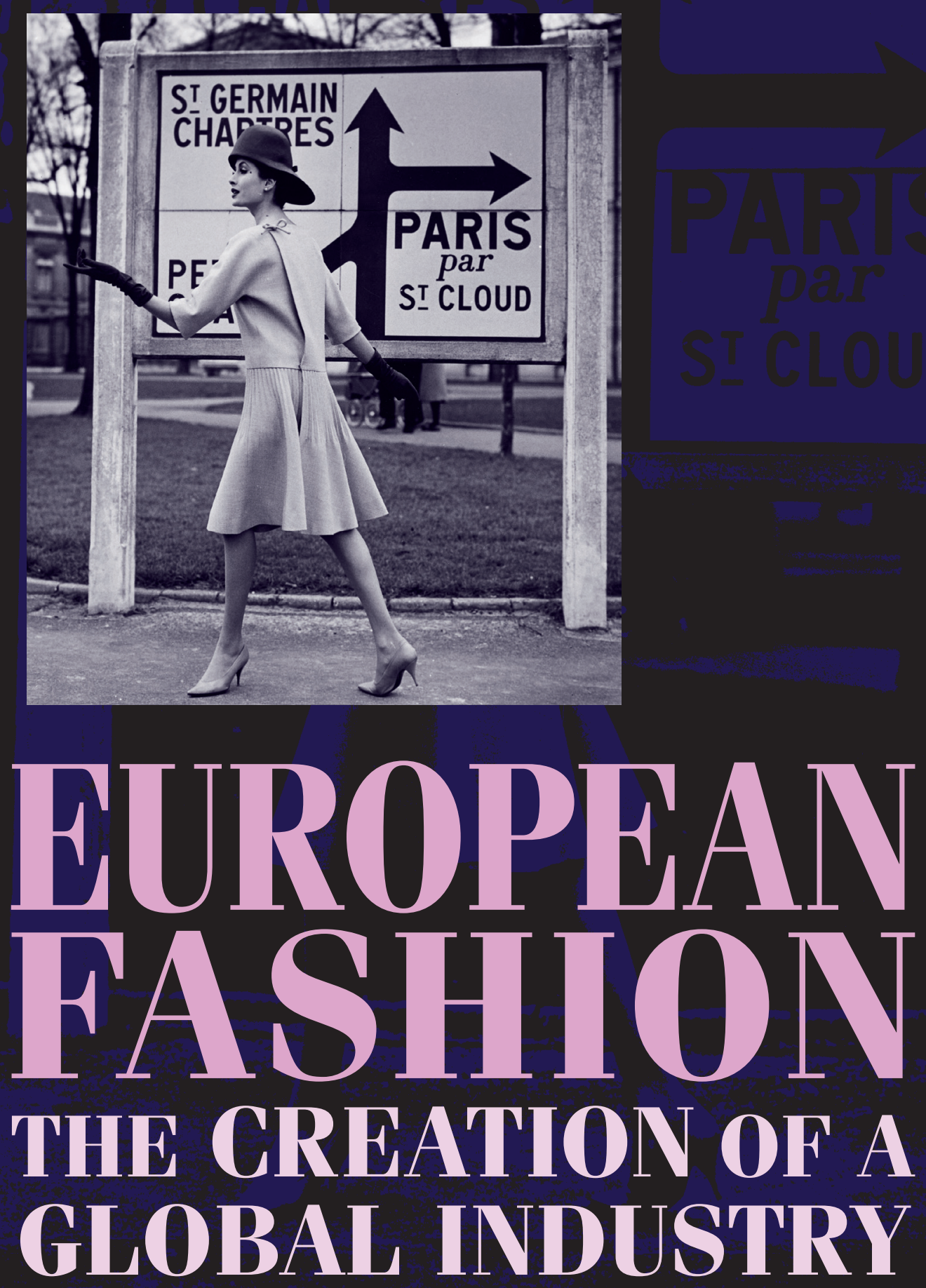

Edited by

Regina Lee Blaszczyk \& Véronique Pouillard 


\section{European fashion}

\section{MANCHESTER 1824}

Manchester University Press 
also available in the series

The matter of Art

Materials, practices, cultural logics, c.1250-1750

EDITED BY CHRISTY ANDERSON, ANNE DUNLOP

AND PAMELA H. SMITH

The culture of fashion

A new history of fashionable dress

CHRISTOPHER BREWARD

The factory in a garden

A history of corporate landscapes from the industrial

to the digital age

HELENA CHANCE

'The autobiography of a nation'

The 1951 Festival of Britain

BECKY E. CONEKIN

The culture of craft

Status and future

EDITED BY PETER DORMER

Material relations

Domestic interiors and the middle-class family, 1850-1910

JANE HAMLETT

Arts and Crafts objects

IMOGEN HART

The material Renaissance

MICHELLE O'MALLEY AND EVELYN WELCH

Bachelors of a different sort

Queer aesthetics, material culture and the modern interior

JOHN POTVIN

Crafting design in Italy

From post-war to postmodernism

CATHARINE ROSSI

Chinoiserie

Commerce and critical ornament in eighteenth-century Britain

STACEY SLOBODA

Material goods, moving hands

Perceiving production in England, 1700-1830

KATE SMITH

Hot metal

Material culture and tangible labour

JESSE ADAMS STEIN

Ideal homes, 1918-39

Domestic design and suburban Modernism

DeBORAH Sugg Ryan

The study of dress history

LOU TAYLOR 


\section{European fashion \\ The creation of a global industry}

Edited by Regina Lee Blaszczyk and Véronique Pouillard

Manchester University Press 
Copyright @ Manchester University Press 2018

While copyright in the volume as a whole is vested in Manchester University Press, copyright in individual chapters belongs to their respective authors, and no chapter may be reproduced wholly or in part without the express permission in writing of both author and publisher.

Published by Manchester University Press

Altrincham Street, Manchester M1 7JA

www.manchesteruniversitypress.co.uk

British Library Cataloguing-in-Publication Data

A catalogue record for this book is available from the British Library

ISBN 9781526122094 hardback

ISBN 9781526122100 paperback

First published 2018

The publisher has no responsibility for the persistence or accuracy of URLs for any external or third-party internet websites referred to in this book, and does not guarantee that any content on such websites is, or will remain, accurate or appropriate.

Sub-editing and picture research by

Mary Schoeser and Diane Mackay

Typeset by

Servis Filmsetting Ltd, Stockport, Cheshire

Front cover image: Pierre Cardin coat dress, 1961. Courtesy Hagley Museum and Library. 